Review

D) Check for updates

\title{
Role of Agmatine on Neuroglia in Central Nervous System Injury
}

\author{
Sumit Barua, Jong Youl Kim, Jong Eun Lee
}

Received: Dec 26, 2018

Revised: Dec 31, 2018

Accepted: Jan 11, 2019

\section{HIGHLIGHTS}

- The primary amine agmatine is neuroprotective after central nervous system (CNS) injury.

Correspondence to

Jong Eun Lee

Department of Anatomy, Yonsei University

College of Medicine, 50-1 Yonsei-ro,

Seodaemun-gu, Seoul 03722, Korea.

E-mail: jelee@yuhs.ac

- The agmatine downregulates the astrogliosis following the CNS injury.

- Agmatine attenuates the detrimental effects of activated microglia in CNS injury.

- Agmatine regulates the astrogliosis and microgliosis via modulating the bone morphogenic proteins expression. 


\section{Review}

\section{Check for updates}

\section{OPEN ACCESS}

Received: Dec 26, 2018

Revised: Dec 31, 2018

Accepted: Jan 11, 2019

Correspondence to

Jong Eun Lee

Department of Anatomy, Yonsei University

College of Medicine, 50-1 Yonsei-ro,

Seodaemun-gu, Seoul 03722, Korea.

E-mail: jelee@yuhs.ac

*Sumit Barua and Jong Youl Kim have contributed equally to this work.

Copyright (c) 2019. Korea Society for Neurorehabilitation

This is an Open Access article distributed under the terms of the Creative Commons Attribution Non-Commercial License (https:// creativecommons.org/licenses/by-nc/4.0) which permits unrestricted non-commercial use, distribution, and reproduction in any medium, provided the original work is properly cited.

ORCID iDs

Sumit Barua (iD)

https://orcid.org/0000-0001-5714-6105

Jong Youl Kim (iD)

https://orcid.org/0000-0002-8340-2894

Jong Eun Lee (iD)

https://orcid.org/0000-0001-6203-7413

\section{Funding}

This work was supported by the National Research Foundation of Korea (NRF) grant funded by the Korea government (MEST) (NRF-2017R1A2B2005350) and the Brain Research Program through the National Research Foundation of Korea (NRF) funded by the Ministry of Science, ICT \& Future Planning (NRF-2016M3C7A1905098).

\section{Role of Agmatine on Neuroglia in Central Nervous System Injury}

\author{
Sumit Barua $\mathbb{B}^{1,1^{*}}$ Jong Youl Kim $\mathbb{( D )},{ }^{1, *}$ Jong Eun Lee $\mathbb{B}^{1,2,3}$ \\ 'Department of Anatomy, Yonsei University College of Medicine, Seoul, Korea \\ ${ }^{2}$ Brain Korea 21 PLUS Project for Medical Science, Yonsei University College of Medicine, Seoul, Korea \\ ${ }^{3}$ Brain Research Institute, Yonsei University College of Medicine, Seoul, Korea
}

\section{ABSTRACT}

Recovery from central nervous system (CNS) injury, such as stroke or spinal cord injury (SCI), largely depends on axonal regeneration, and the neuronal and glial cells plasticity in the lesioned tissue. The lesioned tissue following CNS injury forms a scar that is composed of astrocytes and mixed with connective tissues. At the glial scar, the regenerating axon forms dystrophic endbulbs which do not regenerate and grow beyond the glial scar without a suitable environment. Along with the astrocytes, microglia are also suspected of being involved in necrotic and apoptotic neuronal cell death and the early response to axonal damage in CNS injury. The inflammatory response, a major component of secondary injury and controlled by the microglia, plays a pivotal role in nerve injury and control the regenerative response. As a result, it is very important to control the glial cell function in order to assure the recovery of the CNS injury. Studies have suggested that agmatine, a L-arginine derived primary amine, is a potential modulator of glial cell function after CNS injuries. Agmatine was found to possess anti-inflammatory and neuroprotective characteristics that benefited the rehabilitation process following CNS injury. In this review, we will discuss the effect of agmatine on glial cells in the process of recovery after CNS injury.

Keywords: Agmatine; Astrocyte; Microglia; Glia; CNS Injury

\section{INTRODUCTION}

Central nervous system (CNS) injury is an overwhelming event that can lead to neurological disorder with many sequelae. Due to the immune-privileged and complex nature of the CNS it was believed that the resolution of CNS injury is much more complicated and different from other mammalian tissue repair process. Most of the CNS injury victims develop irreversible disabilities like cognitive impairment, and even paralysis. In the sequelae of CNS injury, both in traumatic brain and spinal cord injury (SCI), the secondary injury following the primary insult is mostly responsible for the irreversible tissue damage [1,2]. Following CNS trauma, the impaired blood-brain barrier (BBB) alongside the brain-cerebrospinal fluid barrier, allows the cellular and chemical infiltration, which disrupts the microenvironment at the lesion site causing the acceleration of the cellular damage, degeneration, and scar formation $[3,4]$. The glial scar formation is believed to be the key player in forming the chemical and physical barrier for the neuronal regeneration, which impair the rehabilitation process after CNS injury [5]. 
Conflict of Interest

The authors have no potential conflicts of interest to disclose.
Following CNS injury, glial cells play an important role in the injury and repair process. The glial cells astrocytes, microglia, oligodendrocytes, and their precursors interact with neuronal cells to maintain the cellular and extracellular microenvironments to exert basic CNS functions. Astrocytes are known to be the key provider of nutrients to the neurons and biochemical support such as ion homeostasis [6], neurotransmitter regulation [7], BBB maintenance [8], and the production of extracellular matrix molecules. They are also the most abundant cells in the mammalian CNS. Following CNS injury, astrocytes can sense the changes in the microenvironment and neuronal activity which influence the structural and functional changes in the astrocytes which eventually protects the brain or deteriorate the repair process $[9,10]$. Microglia, the brain-resident macrophages, surveilling the CNS environment in resting conditions, are central to the modulation of the inflammatory response. When they are activated following infection or injury, they can be transformed into activated form, and can secrete neurotoxic substances and molecules that magnify the immune/inflammatory responses, and retain phagocytic activity [11-13]. Their function in CNS injury has some beneficial effects with respect to neuronal repair and inflammatory resolution. However, in many studies that blocked the innate immune response or anti-inflammatory treatment following CNS injury have found to restore the functional impairments [14-16]. Oligodendrocytes and their progenitors provide myelin sheaths for wrapping the axons, which ensures proper axonal transmission and may also remyelinate in certain pathological conditions [17-19]. Following CNS injury, the loss of the oligodendrocytes results in the loss of axonal myelination followed by impaired motor function and eventually paralysis.

Agmatine, a derivative of L-arginine produced via decarboxylation by arginine decarboxylase (ADC), has been mainly implicated in the study of modulation of neuronal functions [20-22]. Agmatine interacts with different neurotransmitter receptors including the $\mathrm{N}$-methyl-D-aspartate receptor, 2-amino-3-(5-methyl-3-oxo-1,2-oxazol-4-yl) propanoic acid receptor, kainate receptor, acetylcholine receptor, serotonin receptor, $\alpha 2$-adrenoreceptor, and acid-sensing ion channels [23-29]. It has also been suggested that both exogenous and endogenous agmatine is involved in neuroprotection against various CNS injuries, including stroke and SCI. In this review, we will discuss the role of agmatine in the functional modulation of glial cells following CNS injury.

\section{AGMATINE, NEUROGLIA, AND CNS INJURY}

In any CNS injury glial cells play a vital role in the progression of the injury process and repair (Fig. 1). As a result, it is very important to modulate glial function following the onset of the injury until repair to ensure neuro-protection and accelerate the rehabilitation process. Both endogenous (mostly synthesised and stored in astrocytes [30]) and exogenous agmatine were found to be neuroprotective and modulate the function of glial cells.

\section{Regulation of astrocyte function by agmatine in CNS injury}

The most abundant cells in the mammalian CNS can be divided into two subclasses, astrocytes of the grey matter are known as protoplasmic and those in white matter known as fibrous astrocytes [31]. Originating from the neuroepithelial progenitor cells, astrocytes help in neuronal migration, growth, and development of neurons and synapses during mammalian development [32]. The only two diseases which have been found to be directly or partially related to astrocytes are astrocyte gene glial fibrillary associated protein defect 


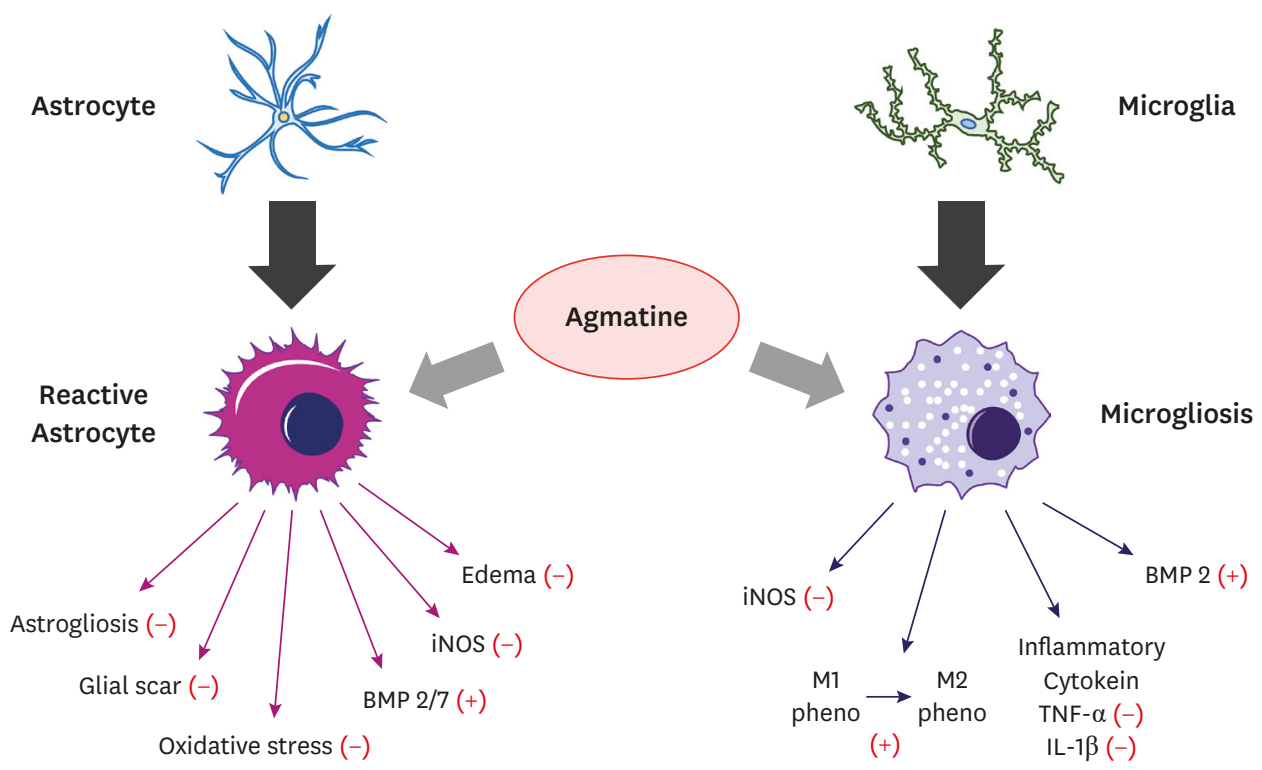

Fig. 1. Agmatine attenuates astrogliosis and microgliosis following CNS injury. Agmatine treatment reduces the detrimental effects of both reactive astrocytes and activated microglia after CNS injury. Agmatine treatment suppresses the M1 microglia and increases the M2 microglia via regulation of the BMPs expression. (-): suppression, $(+)$ : increase of expression.

CNS, central nervous system; BMP, bone morphogenic protein; TNF, tumor necrosis factor; IL, interleukin.

and astrocyte associated hepatic encephalopathy $[33,34]$. However, astrocytes play a very important role in the development and repair process of both chronic and acute diseases such as Alzheimer's disease (AD), Parkinson's disease, amyotrophic lateral sclerosis, Huntington's disease, epilepsy, stroke, SCI and others [35-40]. In the CNS injury, astrocytes respond according to the location and severity of the injury. The post-injury expression of the pro-proliferative cytokines such as interleukin-6, transforming growth factor- $\alpha$, ciliary neurotrophic factor, fibroblastic growth factor-2, and epidermal growth factor are known to increase astrocyte proliferation, leading to reactive astrogliosis and eventually formation of glial scar [41]. The reactive astrocytes present in the glial scar are well known to inhibit the regeneration of severed neurons and shunting neurite outgrowth by the inhibitory extracellular matrix, chondroitin sulphate proteoglycans (CSPGs) [41,42]. The glial scar contributed CSPGs are also reported to be associated with the impairment of neural stem cell migration [43]. Intraperitoneal treatment of agmatine $(100 \mathrm{mg} / \mathrm{kg}$ ) (exogenous) has been found to reduce the severity of middle cerebral artery occlusion (MCAO) induced cerebral astrogliosis, which is also associated with increased neuroprotection via attenuating oxidative stress in rat [44]. To better understand the neuroprotective function of agmatine, Lee et al. treated agmatine in the in vitro primary astrocytes subjected to oxygen-glucose deprivation (OGD). Following OGD astrocyte viability was decreased, which was increased by the agmatine treatment through the nuclear translocation of NF- $\mathrm{kB}$ [45]. Agmatine also reduced the MCAO-induced brain oedema and overexpression of AQP4, a selective water-transporting protein highly expressed in the astrocytic foot process, which play an important role in brain water intoxication [46]. On the other hand, in the chlorpromazine (CPZ) induced rat forebrain injury, agmatine $(75 \mathrm{mg} / \mathrm{kg}$ intraperitoneally [i.p.]) was found to accelerate astrogliosis which overlaps the increased expression of superoxide dismutase and reduction of the reactive oxygen [47]. In this case, the agmatine induced reactive astrocytes might exert their beneficial effect via suppression of the oxidative stress through lipid peroxidation. Agmatine was also found to stabilize the $\mathrm{BBB}$, a principal function of astrocyte 
in rat transient cerebral ischemia [48]. However, the effect of agmatine on astrocytes on the contribution of BBB stabilization was not been reported in this study. Overexpression of endogenous agmatine via transduction of the human $\mathrm{ADC}$ gene was found to reduce oxidative stress injury in in vitro mouse cortical astrocytes [49]. In this study the authors suggested that that the neuroprotective function of endogenous agmatine were exerted via inhibiting inducible nitric oxide synthase (iNOS) signaling and metalloproteinases activity in astrocytes. In the mice SCI, it was also reported that agmatine treatment attenuated reactive astrogliosis and glial scar formation which was correlated with an increase in the level of bone morphogenic proteins 2/4/7 (BMP-2/4/7) [50]. BMP-7 has been suggested to be neuroprotective and a regulator of glial cell differentiation [51,52]. Studies have also suggested that agmatine treatment can also suppress astrogenesis by suppressing BMP-2/7 expression in neuronal stem cells [53]. Thus, agmatine plays a vital role in the formation of reactive astrocytes and glial scar, which eventually modulate the repair and rehabilitation process after CNS injury. Further studies of the mechanism of action of agmatine on astrocytes are needed to ensure its proper therapeutic use in CNS injury.

\section{Regulation of microgliosis by agmatine in CNS injury}

The functional properties of the microglia in the healthy brain are still poorly understood. However, they are well known for their primary surveillance activity in the immune privileged brain, and are also considered to be the key player during the development, homeostasis, and modulation of CNS diseases. Microglia have the ability to scan the whole brain parenchyma within a few hours [54]. In the diseased or injured brain, microglia can be both beneficiary or detrimental to the brain by modulating disease progression and repair process. In $\mathrm{AD}$, frontotemporal dementia, normal aging, axonal pruning has been reported to be associated with an increase in microglial expression of $\mathrm{C} 1 \mathrm{q}$, accompanied by compliment component C3 [55-57]. In damaged tissue, microglia promote the induction of astrocytes associated proinflammatory cytokine expression, such as IL-1 $\alpha$, tumor necrosis factor, and C1q which lead to expression of C3. C3 is considered to be cytotoxic to neurons and oligodendrocytes [58]. CNS injury also induces an astrocyte associated ATP gradient, which is sensed by the microglia through purinergic receptor P2RY12, leading to rapid changes in the microglia and increased microglial migration to the injury site [59,60]. Recent studies have suggested that microglial cells can be present as one of the two phenotypes according to their activation and functional modalities such as either classically activated (M1) or alternatively activated (M2) [61,62]. Among them, M2 microglia are suggested to be beneficial following the CNS injury due to the suppression of inflammation, promoting tissue repair, and wound healing. Following CNS injury, M2 microglia are believed to be express at earlier stages of injury which become pick at 5th day of injury and are later converted to M1 phenotype [63,64]. M1 microglia are suggested to increase the iNOS expression, which promotes neurotoxic NO production in in vitro ischemic condition [63]. In the BV2 microglial cell-mediated in vitro model of the ischemic condition, agmatine $(100 \mu \mathrm{M})$ treatment was found to attenuate the cytotoxic condition and NO production was correlated with the reduction of iNOS production [65]. The authors also suggested that agmatine $(100 \mathrm{mg} / \mathrm{kg}$ i.p.) treatment reduced the expression of ionized calcium binding adaptor molecule 1 (Iba1), which is a well-known marker for microglia and iNOS in the in vivo MCAO rat model. The same research group also found the same effect of agmatine treatment in both in vitro and in vivo (mice) model of lipopolysaccharide (LPS) induced inflammatory injury [66], which supports the results of the LPS-induced iNOS expression and NO production in rat primary cortical microglia [67]. Moreover, they suggested that agmatine can attenuate the expression of pro-inflammatory cytokines, such as tumor necrosis factor- $\alpha$ and interleukin- $1 \beta$, induced by the LPS-injured 
brain [66]. In the CPZ treated oxidative stress model of wistar rats' brain, agmatine reduced the expression of Iba1 [46]. In rat SCI model, agmatine was found to be a modulator of BMP2 expression along with the reduced expression of M1 macrophages which was increased following injury, and increased M2 expression [20]. Recently, BMP-2 has been reported to be a suppressor of M1 macrophages [68]; based on the above results, the authors suggested that agmatine is responsible for the transition of M1 macrophage to M2 via increased BMP-2 expression. Although, agmatine has been found to modulate CNS injury and positively accelerate the repair process, more studies are needed to confirm the therapeutic role of agmatine on microglia and macrophage.

\section{Agmatine promotes myelination by oligodendrocytes in CNS injury}

Oligodendrocytes are the end product of the cell linage with a complex timed program including proliferation, differentiation, migration and later myelination. They are also known as the major myelinating cells, which produces cholesterol myelin sheaths to insulate axons to ensure and accelerate the proper axonal transduction process $[69,70]$. The role of the myelin is not only to ensure axonal signal transduction, but in CNS diseases it may underlie severe functional and rehabilitation disabilities [71,72]. Loss of myelination may happen in different types of diseases or injuries such as genetic, infectious and autoimmune disease, and also following CNS trauma [73-75]. There are not many studies has been found that examine the role agmatine on oligodendrocytes. However, Park YM. et al. suggested that exogenous agmatine treatment promoted remyelination following compression induced SCI in a mouse model that was correlated with the functional neurobehavioral outcome (Fig. 2) [49]. They also suggested that agmatine treatment increased the expression of the Olig-2 $2^{+}$oligodendrocyte cells and also prevented the loss of neuronal cells. The expansion of oligodendrocytes from $\mathrm{NG}^{+}$oligodendrocyte progenitor cells has been reported to be regulated by the higher expression of BMP-2/7 and decreased BMP-4 expression influenced by agmatine [49]. The transplantation of human mesenchymal stem cells overexpressed with the endogenous agmatine-producing gene, ADC, in SCI reduced glial scar formation and promoted neuronal regeneration and oligodendrogenesis [76]. Braissant et al. [77] suggested that the blood to cell exchanger of $\mathrm{L}$-arginine, a substrate of agmatine, cationic amino acid transporters (CAT2) is expressed in neuron and oligodendrocyte, which suggests that the

A

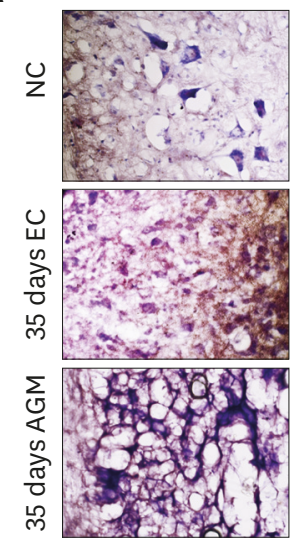

B

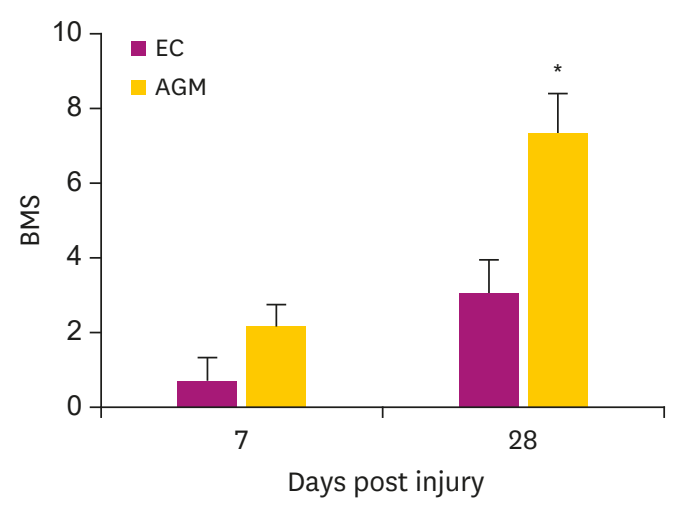

Fig. 2. AGM increases remyelination following CNS injury. (A) AGM treatment increases the remyelination (luxol blue staining) 28 days after $\mathrm{SCl}$ in the rat, which is also correlated with the significantly increased functional outcome compared to experimental control (B). Results represent mean \pm standard error of the mean.

CNS, central nervous system; BMS, basso mouse scale; EC, experimental control; NC, normal control; AGM, agmatine. ${ }^{*} \mathrm{p}<0.05$, EC vs. AGM treated group. 
agmatine might be closely related to oligodendrocytes. These results warrant future studies examining the role of agmatine on oligodendrocytes.

\section{CONCLUSION}

Agmatine has been found to have neuroprotective effect in both acute and chronic CNS disorders. Agmatine modulates different receptors and ion channels that are responsible for the progression and resolution of CNS injury. There are a number of studies that reported that, both endogenous and exogenous agmatine possess beneficiary role on most CNS cells such as neuron, astrocytes, microglia and oligodendrocytes and also modulate the differentiation, proliferation and migration of those cells. Therefore, it is important to understand the mechanism of agmatine action on CNS cells which will help to understand the therapeutic potential of agmatine in CNS injury.

\section{REFERENCES}

1. Corrigan F, Mander KA, Leonard AV, Vink R. Neurogenic inflammation after traumatic brain injury and its potentiation of classical inflammation. J Neuroinflammation 2016;13:264. PUBMED | CROSSREF

2. Okada S. The pathophysiological role of acute inflammation after spinal cord injury. Inflamm Regen 2016;36:20. PUBMED | CROSSREF

3. Moeendarbary E, Weber IP, Sheridan GK, Koser DE, Soleman S, Haenzi B, Bradbury EJ, Fawcett J, Franze K. The soft mechanical signature of glial scars in the central nervous system. Nat Commun 2017;8:14787. PUBMED | CROSSREF

4. Shechter R, Schwartz M. CNS sterile injury: just another wound healing? Trends Mol Med 2013;19:135-143. PUBMED | CROSSREF

5. Popovich PG, Longbrake EE. Can the immune system be harnessed to repair the CNS? Nat Rev Neurosci 2008;9:481-493. PUBMED | CROSSREF

6. Walz W. Role of glial cells in the regulation of the brain ion microenvironment. Prog Neurobiol 1989;33:309-333. PUBMED | CROSSREF

7. Westergaard N, Sonnewald U, Schousboe A. Metabolic trafficking between neurons and astrocytes: the glutamate/glutamine cycle revisited. Dev Neurosci 1995;17:203-211. PUBMED | CROSSREF

8. Abbott NJ. Astrocyte-endothelial interactions and blood-brain barrier permeability. J Anat 2002;200:629-638. PUBMED | CROSSREF

9. Hamby ME, Coppola G, Ao Y, Geschwind DH, Khakh BS, Sofroniew MV. Inflammatory mediators alter the astrocyte transcriptome and calcium signaling elicited by multiple G-protein-coupled receptors. J Neurosci 2012;32:14489-14510. PUBMED | CROSSREF

10. Wanner IB, Anderson MA, Song B, Levine J, Fernandez A, Gray-Thompson Z, Ao Y, Sofroniew MV. Glial scar borders are formed by newly proliferated, elongated astrocytes that interact to corral inflammatory and fibrotic cells via STAT3-dependent mechanisms after spinal cord injury. J Neurosci 2013;33:12870-12886. PUBMED | CROSSREF

11. Fu R, Shen Q, Xu P, Luo JJ, Tang Y. Phagocytosis of microglia in the central nervous system diseases. Mol Neurobiol 2014;49:1422-1434. PUBMED | CROSSREF

12. Kawabori M, Yenari MA. The role of the microglia in acute CNS injury. Metab Brain Dis 2015;30:381-392. PUBMED | CROSSREF 
13. Kreutzberg GW. Microglia: a sensor for pathological events in the CNS. Trends Neurosci 1996;19:312-318. PUBMED | CROSSREF

14. Greenhalgh AD, David S. Differences in the phagocytic response of microglia and peripheral macrophages after spinal cord injury and its effects on cell death. J Neurosci 2014;34:6316-6322. PUBMED | CROSSREF

15. Hussain SF, Yang D, Suki D, Grimm E, Heimberger AB. Innate immune functions of microglia isolated from human glioma patients. J Transl Med 2006;4:15. PUBMED | CROSSREF

16. Lampron A, Elali A, Rivest S. Innate immunity in the CNS: redefining the relationship between the CNS and Its environment. Neuron 2013;78:214-232. PUBMED | CROSSREF

17. Wood P, Bunge RP. The biology of the oligodendrocyte. In: Norton WT, eds. Oligodendroglia. Advances in neurochemistry, vol. 5. Boston, MA: Springer; 1984:1-46.

18. Nishiyama A, Suzuki R, Zhu X. NG2 cells (polydendrocytes) in brain physiology and repair. Front Neurosci 2014;8:133. PUBMED | CROSSREF

19. Wilson HC, Scolding NJ, Raine CS. Co-expression of PDGF alpha receptor and NG2 by oligodendrocyte precursors in human CNS and multiple sclerosis lesions. J Neuroimmunol 2006;176:162-173. PUBMED | CROSSREF

20. Kim JH, Kim JY, Jung JY, Lee YW, Lee WT, Huh SK, Lee JE. Endogenous agmatine induced by ischemic preconditioning regulates ischemic tolerance following cerebral ischemia. Exp Neurobiol 2017;26:380-389. PUBMED | CROSSREF

21. Li G, Regunathan S, Reis DJ. Agmatine is synthesized by a mitochondrial arginine decarboxylase in rat brain. Ann N Y Acad Sci 1995;763:325-329. PUBMED | CROSSREF

22. Seo SK, Yang W, Park YM, Lee WT, Park KA, Lee JE. Overexpression of human arginine decarboxylase rescues human mesenchymal stem cells against $\mathrm{H}_{2} \mathrm{O}_{2}$ toxicity through cell survival protein activation. J Korean Med Sci 2013;28:366-373. PUBMED | CROSSREF

23. Demehri S, Homayoun H, Honar H, Riazi K, Vafaie K, Roushanzamir F, Dehpour AR. Agmatine exerts anticonvulsant effect in mice: modulation by alpha 2-adrenoceptors and nitric oxide. Neuropharmacology 2003;45:534-542. PUBMED | CROSSREF

24. Dias Elpo Zomkowski A, Oscar Rosa A, Lin J, Santos AR, Calixto JB, Lúcia Severo Rodrigues A. Evidence for serotonin receptor subtypes involvement in agmatine antidepressant like-effect in the mouse forced swimming test. Brain Res 2004;1023:253-263. PUBMED | CROSSREF

25. Kotagale NR, Taksande BG, Gahane AY, Ugale RR, Chopde CT. Repeated agmatine treatment attenuates nicotine sensitization in mice: modulation by alpha2-adrenoceptors. Behav Brain Res 2010;213:161-174. PUBMED | CROSSREF

26. Li WG, Yu Y, Zhang ZD, Cao H, Xu TL. ASIC3 channels integrate agmatine and multiple inflammatory signals through the nonproton ligand sensing domain. Mol Pain 2010;6:88. PUBMED | CROSSREF

27. Neis VB, Moretti M, Bettio LE, Ribeiro CM, Rosa PB, Gonçalves FM, Lopes MW, Leal RB, Rodrigues AL. Agmatine produces antidepressant-like effects by activating AMPA receptors and mTOR signaling. Eur Neuropsychopharmacol 2016;26:959-971. PUBMED | CROSSREF

28. Wang G, Gorbatyuk OS, Dayanithi G, Ouyang W, Wang J, Milner TA, Regunathan S, Reis DJ. Evidence for endogenous agmatine in hypothalamo-neurohypophysial tract and its modulation on vasopressin release and Ca2+ channels. Brain Res 2002;932:25-36. PUBMED | CROSSREF

29. Zhu MY, Piletz JE, Halaris A, Regunathan S. Effect of agmatine against cell death induced by NMDA and glutamate in neurons and PC12 cells. Cell Mol Neurobiol 2003;23:865-872. PUBMED | CROSSREF

30. Regunathan S, Feinstein DL, Raasch W, Reis DJ. Agmatine (decarboxylated arginine) is synthesized and stored in astrocytes. Neuroreport 1995;6:1897-1900. PUBMED | CROSSREF

31. Kimelberg HK. Functions of mature mammalian astrocytes: a current view. Neuroscientist 2010;16:79-106. PUBMED | CROSSREF 
32. Ransom B, Behar T, Nedergaard M. New roles for astrocytes (stars at last). Trends Neurosci 2003;26:520-522.

PUBMED | CROSSREF

33. Messing A, Brenner M, Feany MB, Nedergaard M, Goldman JE. Alexander disease. J Neurosci 2012;32:5017-5023.

PUBMED | CROSSREF

34. Brusilow SW, Cooper AJ. Encephalopathy in acute liver failure resulting from acetaminophen intoxication: new observations with potential therapy. Crit Care Med 2011;39:2550-2553. PUBMED | CROSSREF

35. Chu T, Zhou H, Li F, Wang T, Lu L, Feng S. Astrocyte transplantation for spinal cord injury: current status and perspective. Brain Res Bull 2014;107:18-30.

PUBMED | CROSSREF

36. Das MM, Svendsen CN. Astrocytes show reduced support of motor neurons with aging that is accelerated in a rodent model of ALS. Neurobiol Aging 2015;36:1130-1139. PUBMED | CROSSREF

37. de Menezes MF, Nicola F, Vital da Silva IR, Vizuete A, Elsner VR, Xavier LL, Gonçalves CA, Netto CA, Mestriner RG. Glial fibrillary acidic protein levels are associated with global histone $\mathrm{H} 4$ acetylation after spinal cord injury in rats. Neural Regen Res 2018;13:1945-1952. PUBMED | CROSSREF

38. He X, Liu Y, Lin X, Yuan F, Long D, Zhang Z, Wang Y, Xuan A, Yang GY. Netrin-1 attenuates brain injury after middle cerebral artery occlusion via downregulation of astrocyte activation in mice. J Neuroinflammation 2018;15:268. PUBMED | CROSSREF

39. Mathur R, Ince PG, Minett T, Garwood CJ, Shaw PJ, Matthews FE, Brayne C, Simpson JE, Wharton SB; MRC Cognitive Function and Ageing Neuropathology Study Group. A reduced astrocyte response to $\beta$-amyloid plaques in the ageing brain associates with cognitive impairment. PLoS One 2015;10:e0118463. PUBMED | CROSSREF

40. Robel S, Buckingham SC, Boni JL, Campbell SL, Danbolt NC, Riedemann T, Sutor B, Sontheimer H. Reactive astrogliosis causes the development of spontaneous seizures. J Neurosci 2015;35:3330-3345. PUBMED | CROSSREF

41. Cregg JM, DePaul MA, Filous AR, Lang BT, Tran A, Silver J. Functional regeneration beyond the glial scar. Exp Neurol 2014;253:197-207. PUBMED | CROSSREF

42. Yoo JY, Hwang $\mathrm{CH}$, Hong HN. A model of glial scarring analogous to the environment of a traumatically injured spinal cord using kainate. Ann Rehabil Med 2016;40:757-768. PUBMED | CROSSREF

43. Galindo LT, Mundim MT, Pinto AS, Chiarantin GM, Almeida ME, Lamers ML, Horwitz AR, Santos MF, Porcionatto M. Chondroitin sulfate impairs neural stem cell migration through ROCK activation. Mol Neurobiol 2018;55:3185-3195.

PUBMED | CROSSREF

44. Wang CC, Chio CC, Chang CH, Kuo JR, Chang CP. Beneficial effect of agmatine on brain apoptosis, astrogliosis, and edema after rat transient cerebral ischemia. BMC Pharmacol 2010;10:11. PUBMED | CROSSREF

45. Lee WT, Hong S, Yoon SH, Kim JH, Park KA, Seong GJ, Lee JE. Neuroprotective effects of agmatine on oxygen-glucose deprived primary-cultured astrocytes and nuclear translocation of nuclear factor-kappa B. Brain Res 2009;1281:64-70. PUBMED | CROSSREF

46. Manley GT, Fujimura M, Ma T, Noshita N, Filiz F, Bollen AW, Chan P, Verkman AS. Aquaporin-4 deletion in mice reduces brain edema after acute water intoxication and ischemic stroke. Nat Med 2000;6:159-163. PUBMED | CROSSREF

47. Dejanovic B, Stevanovic I, Ninkovic M, Stojanovic I, Lavrnja I, Radicevic T, Pavlovic M. Agmatine protection against chlorpromazine-induced forebrain cortex injury in rats. J Vet Sci 2016;17:53-61. PUBMED | CROSSREF

48. Ahn SS, Kim SH, Lee JE, Ahn KJ, Kim DJ, Choi HS, Kim J, Shin NY, Lee SK. Effects of agmatine on bloodbrain barrier stabilization assessed by permeability MRI in a rat model of transient cerebral ischemia. AJNR Am J Neuroradiol 2015;36:283-288. PUBMED | CROSSREF

49. Hong S, Son MR, Yun K, Lee WT, Park KA, Lee JE. Retroviral expression of human arginine decarboxylase reduces oxidative stress injury in mouse cortical astrocytes. BMC Neurosci 2014;15:99. PUBMED | CROSSREF 
50. Park YM, Lee WT, Bokara KK, Seo SK, Park SH, Kim JH, Yenari MA, Park KA, Lee JE. The multifaceted effects of agmatine on functional recovery after spinal cord injury through Modulations of BMP-2/4/7 expressions in neurons and glial cells. PLoS One 2013;8:e53911. PUBMED | CROSSREF

51. Chang CF, Lin SZ, Chiang YH, Morales M, Chou J, Lein P, Chen HL, Hoffer BJ, Wang Y. Intravenous administration of bone morphogenetic protein-7 after ischemia improves motor function in stroke rats. Stroke 2003;34:558-564. PUBMED | CROSSREF

52. Harvey BK, Hoffer BJ, Wang Y. Stroke and TGF-beta proteins: glial cell line-derived neurotrophic factor and bone morphogenetic protein. Pharmacol Ther 2005;105:113-125. PUBMED | CROSSREF

53. Song HW, Kumar BK, Kim SH, Jeon YH, Lee YA, Lee WT, Park KA, Lee JE. Agmatine enhances neurogenesis by increasing ERK1/2 expression, and suppresses astrogenesis by decreasing BMP 2,4 and SMAD 1,5,8 expression in subventricular zone neural stem cells. Life Sci 2011;89:439-449. PUBMED | CROSSREF

54. Nimmerjahn A, Kirchhoff F, Helmchen F. Resting microglial cells are highly dynamic surveillants of brain parenchyma in vivo. Science 2005;308:1314-1318. PUBMED | CROSSREF

55. Hong S, Beja-Glasser VF, Nfonoyim BM, Frouin A, Li S, Ramakrishnan S, Merry KM, Shi Q, Rosenthal A, Barres BA, Lemere CA, Selkoe DJ, Stevens B. Complement and microglia mediate early synapse loss in Alzheimer mouse models. Science 2016;352:712-716. PUBMED | CROSSREF

56. Lui H, Zhang J, Makinson SR, Cahill MK, Kelley KW, Huang HY, Shang Y, Oldham MC, Martens LH, Gao F, Coppola G, Sloan SA, Hsieh CL, Kim CC, Bigio EH, Weintraub S, Mesulam MM, Rademakers R, Mackenzie IR, Seeley WW, Karydas A, Miller BL, Borroni B, Ghidoni R, Farese RV Jr, Paz JT, Barres BA, Huang EJ. Progranulin deficiency promotes circuit-specific synaptic pruning by microglia via complement activation. Cell 2016;165:921-935. PUBMED | CROSSREF

57. Shi Q, Colodner KJ, Matousek SB, Merry K, Hong S, Kenison JE, Frost JL, Le KX, Li S, Dodart JC, Caldarone BJ, Stevens B, Lemere CA. Complement C3-deficient mice fail to display age-related hippocampal decline. J Neurosci 2015;35:13029-13042. PUBMED | CROSSREF

58. Liddelow SA, Guttenplan KA, Clarke LE, Bennett FC, Bohlen CJ, Schirmer L, Bennett ML, Münch AE, Chung WS, Peterson TC, Wilton DK, Frouin A, Napier BA, Panicker N, Kumar M, Buckwalter MS, Rowitch DH, Dawson VL, Dawson TM, Stevens B, Barres BA. Neurotoxic reactive astrocytes are induced by activated microglia. Nature 2017;541:481-487. PUBMED | CROSSREF

59. Davalos D, Grutzendler J, Yang G, Kim JV, Zuo Y, Jung S, Littman DR, Dustin ML, Gan WB. ATP mediates rapid microglial response to local brain injury in vivo. Nat Neurosci 2005;8:752-758. PUBMED | CROSSREF

60. Haynes SE, Hollopeter G, Yang G, Kurpius D, Dailey ME, Gan WB, Julius D. The P2Y12 receptor regulates microglial activation by extracellular nucleotides. Nat Neurosci 2006;9:1512-1519. PUBMED | CROSSREF

61. Chawla A. Control of macrophage activation and function by PPARs. Circ Res 2010;106:1559-1569. PUBMED | CROSSREF

62. Geissmann F, Gordon S, Hume DA, Mowat AM, Randolph GJ. Unravelling mononuclear phagocyte heterogeneity. Nat Rev Immunol 2010;10:453-460. PUBMED | CROSSREF

63. Hu X, Li P, Guo Y, Wang H, Leak RK, Chen S, Gao Y, Chen J. Microglia/macrophage polarization dynamics reveal novel mechanism of injury expansion after focal cerebral ischemia. Stroke 2012;43:3063-3070. PUBMED | CROSSREF

64. Wang G, Zhang J, Hu X, Zhang L, Mao L, Jiang X, Liou AK, Leak RK, Gao Y, Chen J. Microglia/macrophage polarization dynamics in white matter after traumatic brain injury. J Cereb Blood Flow Metab 2013;33:1864-1874. PUBMED | CROSSREF

65. Ahn SK, Hong S, Park YM, Lee WT, Park KA, Lee JE. Effects of agmatine on hypoxic microglia and activity of nitric oxide synthase. Brain Res 2011;1373:48-54. PUBMED | CROSSREF

66. Ahn SK, Hong S, Park YM, Choi JY, Lee WT, Park KA, Lee JE. Protective effects of agmatine on lipopolysaccharide-injured microglia and inducible nitric oxide synthase activity. Life Sci 2012;91:1345-1350. PUBMED | CROSSREF 
67. Abe K, Abe Y, Saito H. Agmatine suppresses nitric oxide production in microglia. Brain Res 2000;872:141-148. PUBMED | CROSSREF

68. Wei F, Zhou Y, Wang J, Liu C, Xiao Y. The immunomodulatory role of BMP-2 on macrophages to accelerate osteogenesis. Tissue Eng Part A 2018;24:584-594.

PUBMED | CROSSREF

69. Nave KA, Trapp BD. Axon-glial signaling and the glial support of axon function. Annu Rev Neurosci 2008;31:535-561.

PUBMED | CROSSREF

70. Simons M, Nave KA. Oligodendrocytes: myelination and axonal support. Cold Spring Harb Perspect Biol 2015;8:a020479.

PUBMED | CROSSREF

71. Duncan ID, Radcliff AB. Inherited and acquired disorders of myelin: the underlying myelin pathology. Exp Neurol 2016;283:452-475. PUBMED | CROSSREF

72. Taib T, Leconte C, Van Steenwinckel J, Cho AH, Palmier B, Torsello E, Lai Kuen R, Onyeomah S, Ecomard K, Benedetto C, Coqueran B, Novak AC, Deou E, Plotkine M, Gressens P, Marchand-Leroux C, Besson VC. Neuroinflammation, myelin and behavior: temporal patterns following mild traumatic brain injury in mice. PLoS One 2017;12:e0184811. PUBMED | CROSSREF

73. Almad A, Sahinkaya FR, McTigue DM. Oligodendrocyte fate after spinal cord injury. Neurotherapeutics 2011;8:262-273. PUBMED | CROSSREF

74. Popescu BF, Lucchinetti CF. Pathology of demyelinating diseases. Annu Rev Pathol 2012;7:185-217. PUBMED | CROSSREF

75. Shi H, Hu X, Leak RK, Shi Y, An C, Suenaga J, Chen J, Gao Y. Demyelination as a rational therapeutic target for ischemic or traumatic brain injury. Exp Neurol 2015;272:17-25. PUBMED | CROSSREF

76. Park YM, Han SH, Seo SK, Park KA, Lee WT, Lee JE. Restorative benefits of transplanting human mesenchymal stromal cells overexpressing arginine decarboxylase genes after spinal cord injury. Cytotherapy 2015;17:25-37. PUBMED | CROSSREF

77. Braissant O, Gotoh T, Loup M, Mori M, Bachmann C. Differential expression of the cationic amino acid transporter 2(B) in the adult rat brain. Brain Res Mol Brain Res 2001;91:189-195.

PUBMED | CROSSREF 